\title{
HLA-DR4 in ankylosing spondylitis with different patterns of joint involvement
}

\author{
W MIEHLE, ${ }^{1}$ M SCHATTENKIRCHNER, ${ }^{2}$ D ALBERT ${ }^{3}$ AND M BUNGE \\ From the ' Klinik Wendelstein, Rheumazentrum der BfA, 8202 Bad Aibling, Kolbermoorer Str. 56; the \\ ${ }^{2}$ Universitätspoliklinik, 8000 München, Pettenkoferstr. 8; and the ${ }^{3}$ Universitätskinderpoliklinik, 8000 \\ München, Pettenkoferstr. 20, West Germany
}

SUMMARY Fifty patients with ankylosing spondylitis (AS) confined to the spine and sacroiliac joints were compared with 50 cases of AS complicated by various patterns of non-axial joint involvement. Radiological and clinical features were evaluated and HLA-DR4 typing was carried out. This antigen was found in $16 \%$ of 200 normal individuals in $18 \%$ of patients suffering from exclusively axial AS, and in $54 \%$ of patients with additional purely peripheral joint involvement (wrist, finger, ankle, toe). The possibility that HLA-DR4 represents a non-specific marker for peripheral arthritis in patients with ankylosing spondylitis is discussed.

Key-words: non-axial joint involvement, non-specific marker, rheumatoid arthritis, ankylosing spondylitis, tissue typing.

Ankylosing spondylitis (AS) is a chronic inflammatory disease of the locomotor system which may involve other systems. The disease progresses at a varying rate, is incurable, and may become inactive at any point in its course.

Non-axial joints are involved in 18 to $75 \%$ of cases of $\mathrm{AS}^{1}{ }^{2}$ mainly in young patients. Such cases are often diagnosed only retrospectively as AS with the aid of tests for HLA-B27. Arthralgias or arthritides generally begin in one or only a few joints, are frequently transient, and represent in $10-20 \%$ of cases the prodromal signs of spinal disease. The joints most commonly affected, with a frequency of up to $40 \%$, are the hips and shoulders. ${ }^{3}$ In contrast, disease affecting only the peripheral joints (ankle, toe, hand, and finger joints) is considerably rarer, being described in some $8-14 \%$ of cases.

The role of HLA-B27 in the diagnosis, risk assessment, and aetiology of AS is well known. With a disease prevalence of $0.05 \%$, only $0.75 \%$ of randomly investigated individuals found to be positive for HLA-B27 later develop AS. Assuming a prevalence of $1 \%$ increases this figure to $15 \%$, but even here 85 out of each 100 HLA-B27 positive

Accepted for publication 5 July 1984

Correspondence to Dr med Wolfgang Miehle, Klinik Wendelstein, Rheumazentrum der BfA, Kolbermoorer Str. 56, 8202 Bad Aibling. West Germany. persons remain 'free of AS.' In contrast to the finding of HLA-B27 positivity, a negative finding has great diagnostic relevance. The likelihood of an HLA-B27 negative individual developing AS is only $0,1 \%{ }^{4}$

An increased occurrence of AS is found neither for other antigens of the $B$ locus nor for those of the loci for A (with the exception of HLA-A2, which shows a linkage disequilibrium with B27), C, D, or DR.

Peripheral arthritis (PA) in AS, defined as affecting only ankle, toe, hand, and finger joints, is often indistinguishable radiomorphologically and histologically from rheumatoid arthritis (RA). In this context the emergence over the last few years of a correlation between RA and HLA-DR4 in some $50-60 \%$ of cases prompted us to examine the frequency of HLA-DR4 in AS with and without involvement of various joints outside the axial skeleton.

\section{Patients and methods}

The study was carried out at the Klinik Wendelstein, Rheumazentrum der BfA, 8202 Bad Aibling, West Germany, between May 1982 and October 1983. Included in the study were 50 patients with AS restricted to the axial skeleton (typical changes in the sacroiliac joints and spine) and 50 patients with 


\section{Table 1 Diagnostic criteria for ankylosing spondylitis ${ }^{5}$}

\section{Clinical criteria}

(1) Deep lumbar pain and stiffness for more than 3 months not improved by rest

(2) Pain and stiffness in thoracic region

(3) Limitation of mobility in lumbar spine

(4) Limited expansibility of rib cage (respiratory movement)

(5) History or objective evidence of iritis or its sequelae

\section{$X$-ray criteria}

Radiologically shown bilateral changes of sacroiliac joints characteristic of ankylosing spondylitis (not arthrosis!).

Table 2 Standardised radiographic evaluation of arthritides $^{6}$

\section{Grade 0: Normal joints}

Grade 1: Slight abnormality

One or more of the following lesions must be present:

soft tissue swelling

periarticular osteoporosis

slight joint space narrowing

These criteria should always be substantiated by comparison with a healthy contralateral joint or with an earlier film of the same joint

Grade 2: Definite early abnormality

Erosion and moderate joint space narrowing.

Erosion is obligatory except in the weight-bearing joints.

Grade 3: Medium destructive abnormality

Erosion and marked joint space narrowing.

Grade 4: Severe destructive abnormality

Erosion, severe joint space narrowing.

Bone deformation in weight-bearing joints.

Grade 5: Mutilating abnormality

AS complicated by non-axial joint involvement of varying kinds. Various clinical, radiological, and laboratory investigations were carried out, and the presence or absence of HLA-DR4 was ascertained in each patient.

The diagnosis of ankylosing spondylitis was established according to Kellgren's criteria ${ }^{5}$ (Table 1). We excluded cases of AS which had begun in childhood, all other seronegative spondylarthritides, and all chronic or acute polyarthritides without the axial involvement typical of AS. Peripheral joint
Table 3 Age and sex distribution of investigated cases of $A S$

\begin{tabular}{|c|c|c|c|}
\hline Patient group & Number & Mean age & Men:womeñ \\
\hline Axial AS & 50 & 43 years & $4 \cdot 5: 1$ \\
\hline $\begin{array}{l}\text { AS with non-axial } \\
\text { joint involvement }\end{array}$ & 50 & 41.5 years & $3 \cdot 5: 1$ \\
\hline
\end{tabular}

Table 4 Different forms of non-axial joint involvement in the investigated cases of $A S$

\begin{tabular}{ll}
\hline Patient group & Number of cases \\
\hline $\begin{array}{l}\text { AS with non-axial joint involvement } \\
\text { AS with purely peripheral involvement } \\
\text { (ankle, toe, hand, finger joints) }\end{array}$ & 50 \\
$\begin{array}{l}\text { AS with involvement of peripheral } \\
\text { joints + elbow/knee }\end{array}$ & 13 \\
$\begin{array}{l}\text { AS with involvement of peripheral } \\
\text { joints, elbow/knee + hip/shoulder }\end{array}$ & 15 \\
\hline
\end{tabular}

involvement, defined as affecting only ankle, toe, $\vec{\oplus}$ hand, and finger joints, was established by the $e^{\text {. }}$ history (swelling, pain, effusion), clinical manifesta-tions (synovitis, effusion) and, above all, by $x$-ray criteria $^{6}$ (Table 2). A history of peripheral joint paino or inflammation not substantiated by objective气 evidence was not considered to be proof of peri- $\stackrel{\mathbb{Q}}{2}$ pheral joint involvement.

Tissue typing was carried out in the National Reference Laboratory (Professor Dr D. Albert), Universitätspolikinderklinik, Pettenkoferstr. 20, 8000 München, West Germany. HLA-B27 was determined by a standardised lymphocyte toxicityo test and HLA-DR4 with the aid of B cell prepara-O tions. The results obtained were compared by means of the $\chi^{2}$ test with the Yates's correction. Relative risk (RR) was calculated with the formula: $\mathrm{RR}=(\mathrm{P}+) \times(\mathrm{C}-) /(\mathrm{P}-) \times(\mathrm{C}+)$, where $\mathrm{P}+$ and $\mathrm{P}-\mathrm{O}$ are the number of patients and $\mathrm{C}+$ and $\mathrm{C}-$ the number of controls positive and negative for HLADR4 respectively.

Table $5 \quad H L A-D R 4$ and HLA-B27 in AS with and without various forms of non-axial joint involvement

\begin{tabular}{|c|c|c|c|c|}
\hline Patient group & Number & $H L A-B 27+\%$ & Number & $H L A-D R 4+\%$ \\
\hline Control group & - & $4-10^{*}$ & 200 & 16 \\
\hline Purely axial AS & 50 & 94 & 50 & 18 \\
\hline AS with and without non-axial joint involvement 1 & 1100 & 94 & 100 & 25 \\
\hline AS with non-axial joint involvement & 50 & 94 & 50 & 32 \\
\hline AS with exclusively peripheral joint involvement & t 13 & $92 \cdot 3$ & 13 & 54 \\
\hline
\end{tabular}

${ }^{*}$ Kelsey. ${ }^{8}$ 
Table 6 Nature of peripheral joint involvement, $H L A-D R 4$, peripheral and axial $x$-ray findings, history, and clinical findings in the 13 patients with pure peripheral arthritis

\begin{tabular}{|c|c|c|c|c|c|}
\hline $\begin{array}{l}\text { Serial } \\
\text { number }\end{array}$ & $\begin{array}{l}\text { Age }(y r) \text {, } \\
\text { Sex }\end{array}$ & $\begin{array}{l}X \text {-ray findings in SI joints and } \\
\text { spine }\end{array}$ & $\begin{array}{l}\text { Peripheral joint involvement: } \\
\text { (a) History } \\
\text { (b) Clinical findings } \\
\text { (c) X-ray }\end{array}$ & $\begin{array}{l}\text { Radiographic } \\
\text { classification } \\
\text { of peripheral } \\
\text { arthritis according } \\
\text { to Larsen et al. } \\
\text { Stages } 0-5\end{array}$ & $\begin{array}{l}H L A-D R 4 \\
+/-\end{array}$ \\
\hline
\end{tabular}

$1 \quad 44, M \quad$ Ankylosis of SIJ, syndesmophytes

$a+b+c:$ right forefoot

c: right MTP joints II, III: erosions,

subluxations

\begin{tabular}{|c|c|c|c|c|c|}
\hline 2 & $39, \mathrm{M}$ & $\begin{array}{l}\text { Ankylosis of SIJ, syndesmophytes } \\
\text { spondylarthritis, diskitis }\end{array}$ & $\begin{array}{l}a+b+c: \text { left ankle } \\
c: \text { increased isotope uptake }\end{array}$ & 0 & + \\
\hline 3 & $41, M$ & $\begin{array}{l}\text { Bilateral sacroiliitis, syndesmo- } \\
\text { phytes, vertebral squaring, } \\
\text { spondylarthritis }\end{array}$ & $\begin{array}{l}a+b+c(c) \text { : right } \mathrm{MCP} \text { joints II, III } \\
\mathrm{c:} \text { Above all, interruption of articular } \\
\text { cortex in right MCP joint II }\end{array}$ & 1 & + \\
\hline 4 & $41, M$ & $\begin{array}{l}\text { Bilateral sacroiliitis, post- } \\
\text { inflammatory fusion of } \\
\text { cervical spine, enthesitis in } \\
\text { C5/C6 }\end{array}$ & $\begin{array}{l}\text { a+c: bilateral MTP joints V; } \\
\text { c: narrowing of joint space, } \\
\text { osteoporosis, interruption of } \\
\text { articular cortex }\end{array}$ & 1 & - \\
\hline 5 & $42, M$ & $\begin{array}{l}\text { Florid bilateral sacroiliitis, } \\
\text { syndesmophytes, spondylarthritis }\end{array}$ & $\begin{array}{l}\mathrm{a}+\mathrm{b}+\mathrm{c}: \text { right MTP joints } \mathrm{II}-\mathrm{V} \text {; } \\
\mathrm{c:} \text { right MTP joint II: erosion, } \\
\text { narrowing of joint space }\end{array}$ & 2 & + \\
\hline 6 & 36. M & Florid bilateral sacroillitis* & $\begin{array}{l}a+b+c \text { : left MTP joints III. IV; } \\
c: \text { narrowing of joint space. erosion, } \\
\text { pseudocyst }\end{array}$ & 2 & + \\
\hline 7 & 39. M & $\begin{array}{l}\text { Ankylosis of SIJ, syndesmophytes, } \\
\text { ventral atlantoaxial dislocation }\end{array}$ & $\begin{array}{l}a+b+c \text { : right MTP joints II-V; } \\
c \text { : osteoporosis, erosion, luxation }\end{array}$ & 3 & - \\
\hline 8 & $45, F$ & Florid bilateral sacroiliitis ${ }^{*}$ & $\begin{array}{l}a+b: \text { marked synovitis in region of } \\
\text { right wrist; marked limitation of } \\
\text { movement } \\
c:-\end{array}$ & 0 & + \\
\hline 9 & $50, \mathrm{~F}$ & $\begin{array}{l}\text { Bilateral sacroiliitis, vertebral } \\
\text { squaring, syndesmophytes, } \\
\text { spondylarthritis }\end{array}$ & $\begin{array}{l}a+b+c: \text { left ankle } \\
\text { c: osteoporosis, pseudocyst }\end{array}$ & 1 & + \\
\hline 10 & 30, $\mathrm{F}$ & Florid sacroiliitis* & $\begin{array}{l}a+b+c: \text { right MTP joints II-V, left } \\
\text { MTP joints III, IV } \\
c \text { : erosion, narrowing of joint space, } \\
\text { subluxation }\end{array}$ & 3 & - \\
\hline 11 & 57, M & $\begin{array}{l}\text { Ankylosis of SIJ, syndesmophytes, } \\
\text { spondylarthritis. Above all, } \\
\text { diskitis }\end{array}$ & $\begin{array}{l}a+b+c: \text { left wrist } \\
c: \text { osteoporosis, narrowing of joint } \\
\text { space }\end{array}$ & 1 & - \\
\hline 12 & $19, \mathrm{~F}$ & Florid bilateral sacroiliitis* & $\begin{array}{l}a+b+c: \text { right MTP joint II } \\
c: \text { pseudocyst. interruption of } \\
\text { articular cortex }\end{array}$ & 2 & - \\
\hline 13 & 44, M & $\begin{array}{l}\text { Bilateral sacroiliitis, } \\
\text { spondylarthritis, costovertebral } \\
\text { arthritis, vertebral squaring }\end{array}$ & $\begin{array}{l}a+b+c: \text { forefoot } \\
c: \text { osteoporosis, pseudocyst, erosion, } \\
\text { mutilation }\end{array}$ & 4 & - \\
\hline
\end{tabular}

*The diagnosis of these cases of AS was confirmed by additional clinical and anamnestic criteria (e.g., heel pain, iritis, morning lumbar pain). 
Table 7 HLA-DR4 in AS with various forms of non-axial joint involvement

\begin{tabular}{lll}
\hline Patient group & Number & $\begin{array}{l}\text { HLA-DR4 positive } \\
(\%)\end{array}$ \\
\hline $\begin{array}{l}\text { Control group } \\
\text { Peripheral joint involvement }+ \\
\text { elbows/knees }\end{array}$ & 200 & 16 \\
$\begin{array}{l}\text { Exclusively peripheral joint } \\
\text { involvement }\end{array}$ & 15 & 26.6 \\
\hline
\end{tabular}

Table 8 'Rheumatoid factor' and family history in various courses of $A S$

\begin{tabular}{llll}
\hline Patient group & Number & $\begin{array}{l}\text { Demonstration of } \\
R F \text { (latex fixation } \\
\text { test and/or SCAT) } \\
(\%)\end{array}$ & $\begin{array}{l}\text { Family } \\
\text { history } \\
\text { of } A S \\
(\%)\end{array}$ \\
\hline $\begin{array}{l}\text { AS with no non- } \\
\text { axial joint } \\
\text { involvement }\end{array}$ & 50 & 2 & 12 \\
$\begin{array}{l}\text { AS with non- } \\
\text { axial joint } \\
\text { involvement }\end{array}$ & 50 & 10 & 10 \\
$\begin{array}{l}\text { AS with } \\
\text { exclusively } \\
\text { peripheral joint } \\
\text { involvement }\end{array}$ & 13 & 0 & 14 \\
\hline
\end{tabular}

'Rheumatoid factor' positive in $4-8 \%$ of control group.

Family history of AS according to literature in approximately $6 \% .{ }^{15}$

\section{Results}

A profile of the patients in terms of age and sex is given in Table 3. Of particular interest in this study were the 50 patients with non-axial joint involve- ment. In Table 4 this group is subdivided into those. with peripheral arthritis, those with PA and addi $\overrightarrow{=}$ tional involvement of the knees or elbows, and? finally those with in addition involvement of shoulders or hips. The occurrence of HLA-B27 and HLA-DR4 in the various groups is shown in Table 5. Peripheral and axial radiological findings are given for the individual patients with purely PA inow Table 6, together with their HLA-DR4 status. $\vec{\circ}$

For each of the disease patterns described abovewe determined HLA-DR4 frequencies, as shown incw Table 7.

We attempted to establish correlations between⿳亠口冋口 AS with varying joint involvement and a family history of AS, the presence of 'rheumatoid factor,"'and the combination of HLA-DR4 and HLA-B27, as well as between HLA-DR4 positivity and theo severity of the radiological changes.

In Table 8 the patients with PA are analysed withe respect to the presence of 'rheumatoid factor' and a气 family history of AS.

There exists no linkage disequilibrium between HLA-DR4 and HLA-B27 which might modify theco percentage frequencies of HLA-DR4 in our sub-or groups. The differences between the control groupD and, on the one hand, the patients with AS restricted to the spine $(n=50)$ and, on the other hand, those with PA were not significant. Compari-a son between the relative frequency of HLA-DR4 in⿳亠丷⿵冂丶 those AS patients with no non-axial joint involvement and in patients with PA gave $\chi^{2}=7 \cdot 8$, $\mathrm{p}=0.005$. Comparison between AS with PA and the group with additional involvement of knees, elbows, hips, and shoulders gave $\chi^{2}=5 \cdot 5, p=0.002$ (with Yates's correction).

AS patients positive for HLA-DR4 were calculated to have a 7 -fold relative risk of developing a

Table $9 \quad H L A-D R 4$ in rheumatoid arthritis

\begin{tabular}{|c|c|c|c|c|c|}
\hline Authors & $\begin{array}{l}\text { Control } \\
\text { group } \\
(\%)\end{array}$ & $\begin{array}{l}\text { Number of } \\
\text { cases of } \\
\text { (n) }\end{array}$ & $\begin{array}{l}\text { Seropositive }+ \\
\text { seronegative } R A \\
(\%)\end{array}$ & $\begin{array}{l}\text { Seronegative RA } \\
(\%)\end{array}$ & $\begin{array}{l}\text { Seropositive } R A \\
(\%)\end{array}$ \\
\hline Dubloug et al. ${ }^{16}$ & 27 & 48 & 50 & 27 & 61 \\
\hline Sakurami et al. ${ }^{17}$ & 33 & 50 & 56 & 33 & 59 \\
\hline Swiss Coll. ${ }^{18}$ & 19 & 132 & 44 & 23 & 50 \\
\hline Queiros et al. ${ }^{19}$ & 12 & 80 & 49 & 39 & 90 \\
\hline Alarcón et al. ${ }^{20}$ & 14 & 130 & 44 & 27 & 56 \\
\hline Scherak et $a l .^{9}$ & 21 & 111 & 54 & 42 & 57 \\
\hline Total/average & 21 & 551 & 49.5 & 32 & 62 \\
\hline
\end{tabular}


purely PA. This risk was similar to that of an HLA-DR4 positive individual developing rheumatoid arthritis.

Our investigations showed no correlations between HLA-DR4 and HLA-B27 positivity or negativity, between HLA-DR4 and a family history of AS, nor between HLA-DR4 and the presence of 'rheumatoid factor.'

\section{Discussion}

The type of AS with additional involvement of only the peripheral joints was formerly described as the 'Scandinavian form' and sometimes thought of as being intermediate between AS and seronegative RA. The term 'Scandinavian form' has today been abandoned. Moreover, it is now accepted that the occurrence of both diseases in one person is extremely rare, only some 30 cases of true coexistence between RA and AS having been reported. ${ }^{7}$ The prevalence of peripheral arthritis in our series of AS patients is consistent with that generally reported. The nature of the joint involvement differs from the symmetrical and ordinarily polyarthritic pattern typical of RA. Here an asymmetrical and mono- or pauciarticular pattern is normally seen. However, inability to distinguish between the two diseases on the basis of $x$-ray appearance or synovial membrane histology led, as late as the middle of 1950 s, to use in America of the term 'rheumatoid spondylitis'conceived of as being a variant of rheumatoid arthritis.

In adult rheumatoid arthritis the HLA-DR4 antigen is much more common than in healthy reference populations. The risk of an HLA-DR4 positive individual developing rheumatoid arthritis is six times greater than for someone not possessing this antigen. ${ }^{8}$ HLA-DR4 correlates most strongly with seropositive forms of the disease (Table 9). Several recent publications have, however, found no difference between the occurrence of HLA-DR4 in seropositive and seronegative rheumatoid arthritis. ${ }^{9}$ The HLA-DR4 gene locus probably lies in close proximity to genetic structures which regulate the immune response and are thus capable of inducing certain pathological reactions. By further genetic analyses it may be possible in the future to find differences between seronegative and seropositive rheumatoid arthritis and thus to create new areas of definition for subgroups of the entity 'adult RA. ${ }^{10}$

So far no association between ankylosing spondylitis and HLA-DR4 has been established. ${ }^{12}{ }^{13}$ In 1983 Armstrong and coworkers ${ }^{14}$ investigated 33 patients with AS for the presence of HLA-DR4 and other antigens. In 15 patients without peripheral arthritis and 18 patients with peripheral arthritis (including hip or shoulder involvement) HLA-DR4 was found with a frequency of 33.3 and $22.2 \%$ respectively, as opposed to $33.8 \%$ in the healthy controls.

In contrast to these findings the occurrence of HLA-DR4 in our patients with purely peripheral joint involvement (ankle, toe, finger, wrist) was, at $54 \%$, comparable with the frequency in seropositive rheumatoid arthritis, and markedly higher than in the control group $(16 \%)$. Comparison between the occurrence of HLA-DR4 in exclusively axial AS and patients with peripheral joint involvement gives $\chi^{2}$ $=7.8(p=0.005)$. Comparison of AS with PA and the group with manifestations in the knees, elbows, hips, and shoulders gives $\chi^{2}=5 \cdot 5 \quad(p=0 \cdot 02)$.

From our results it can be calculated that AS patients positive for HLA-DR4 have a 7-fold relative risk of developing a peripheral arthritis. This distribution of HLA-DR4 between the various subgroups raises the following questions:

(1) Is HLA-DR4 a non-specific marker for peripheral arthritides which codes for peripheral joint involvement in the context of ankylosing spondylitis?

(2) Is the risk of peripheral joint involvement in HLA-DR4 positive AS patients higher than in DR4 negative patients?

(3) Is AS with peripheral joint involvement in fact a separate disease entity, despite being indistinguishable on the basis of $x$-ray appearance and synovial membrane histology?

Further investigations, with greater numbers of cases, are needed to provide a clear answer to these questions.

\section{References}

1 Boland E W. Present A J. Rheumatoid spondylitis. A study of one hundred cases with special reference to diagnostic criteria. JAMA 1945; 129: 843.

2 Romanus R. Yden S. Pelvo-spondylitis ossificans-rheumatoid or ankylosing spondylitis. Copenhagen: Munksgaard, 1955.

3 Schilling F. Spondylitis ankylopoetica, die sogenannte Bechterewsche Krankhcit und ihre Differentialdiagnose. In: Diethclm L. ed. Handbuch der medizinischen Radiologie. Berlin. Heidelberg. New York: Springer, 1974; 6(2): 452-689.

4 Hawkins B R. Dawkins R L. Christiansen F T, Zilko P J. Use of the B27 test in the diagnosis of ankylosing spondylitis: a statistical cvaluation. Arthritis Rheum 1981; 24: 743-6.

5 Kellgren J H. The cpidemiology of rhcumatic discases. Ann Rheum Dis 1964: 23: 109-22.

6 Larsen A. Dalc K. Eck M. Radiographic evaluation of rhcumatoid arthritis and related conditions by standard refercnce films. Acta Radiol Diagn 1976; 18: 481-91.

7 Alexander E L. Bias W B. Arnett F C. The coexistence of rhcumatoid arthritis with Reiter's syndrome and/or ankylosing spondylitis: a model of dual HLA-associated discasc susceptibility and cxpression. J Rheumatol 1981: 83: 398-404.

8 Kelsey J L. Epidemiology of muskuloskeletal disorders. New York. Oxford: Oxford University Press. 1982: 92. 99. 
9 Scherak O. Smolen J S, Mayr W R. HLA-DR antigens and disease patterns of rheumatoid arthritis. Rheumatol Int 1983: 3: 113-6.

10 Fehr K, Böni A. Gelenke. In: K O Vorlaender, ed. Immunologie. Stuttgart. New York: Thieme 1983: 465-501.

11 Gaucher A, Raffoux C. Netter P. Faure G. Pourel J, Streiff F. HLA DR Dans la Spondylarthrite ankylosante. Rev Rhum Mal Osteoartic 1978: 45: 335-8.

12 Kemple K, Gatti R A. Liebold W, Klinenberg I, Bluestone R. HLA-D locus typing in ankylosing spondylitis and Reiter's syndrome. Arthritis Rheum 1979; 22: 371-5.

13 Roy R. Hérbert J, Latulippe L, Latulippe L. Possible association between HLA-DR locus and ankylosing spondylitis. Arthritis Rheum 1979; 22: 95-5.

14 Armstrong R D. Panayi G S, Welsh K I. Histocompatibility antigens in psoriasis, psoriatic arthropathy and ankylosirf spondylitis. Ann Rheum, Dis 1983: 42: 142-6.

15 Miehle W. Spondylitis ankylosans. In: Mathies H, ed. Han $\overline{\bar{d}}$ buch der inneren Medizin. Berlin. Heidelberg, New Yort Springer, 1983: 6: 3-106.

16 Dobloug J H, Øystein F, Kåss E, Thorbsy E. HLA-antige O and rheumatoid arthritis. Arthritis Rheum 1980; 23: 3(1)-1

17 Sakurami T, Ueno Y. Okumura H. et al. HLA-DR specificiti among Japanese with rheumatoid arthritis. Arthritis Rheum 1981; 24: 866 .

18 Swiss Collaborative Study. HLA-DR antigens in rheumatoin arthritis. Rheumatol Int 1981; 1: 111-3.

19 Queirós M V. Sancho M R H. Caetano J M. HLA-DR4 antigef and IgM rheumatoid factors. $J$ Rheumatol 1982; 93: 370- $\mathcal{W}$

20 Alarcón G S, Koopman W J, Acton, R T, Barger B فे Seronegative rheumatoid arthritis. A distinct immunogenet disease? Arthritis Rheum. 1982; 25: 502-7. 